\title{
Benthic faunal response to a high energy gradient
}

\author{
A. McLachlan, A. C. Cockcroft and D. E. Malan \\ Zoology Department, University of Port Elizabeth, P. O. Box 1600, Port Elizabeth 6000, South Africa
}

\begin{abstract}
Macrofauna and meiofauna were quantitatively sampled along 3 transects through high energy surf zones to nearshore waters. While 1 transect included some gravel patches, the other 2 exhibited increasingly finer sand and more silt and clay fraction with distance beyond the breaker zone. Meiofaunal abundance and biomass increased beyond the breakers and then decreased again further offshore. Macrofaunal abundance and diversity increased offshore; biomass increased offshore in one case while it reached a peak a little way beyond the breakers in the other. Numerical classification revealed 3 macrofaunal assemblages. The first occupied the surf zone or inner turbulent zone and included species characteristic of the sublittoral fringe of intertidal sandy beaches. The third assemblage occupied the outer turbulent zone; it started well beyond the break point and was marked by a rapid increase in biomass and diversity. The second assemblage represents a transition zone between these 2. It had no unique species but included reduced numbers of some species typical of both inner and outer turbulent zones. This transition zone, just outside the breakers, marks the region where wave energy reaching the bottom rapidly declines from its peak at the break point. A zonation scheme for the intertidal and subtidal macrofauna of high energy sandy coasts is proposed and implications of this are discussed.
\end{abstract}

\section{INTRODUCTION}

High energy surf zones have been even more neglected in marine ecological studies than their adjacent high energy sandy beaches. While this is understandable because of the problems and dangers of working in such environments, it does not negate the need for information on these systems. Indeed, it has been suggested that beaches and their surf zones should be seen in conjunction as inshore ecosystems (McLachlan, $1980 \mathrm{a}, \mathrm{b}$ ) and that the food chains of such systems are concentrated in the surf zone (McLachlan, 1983). The outer limit of surf circulation cells has been suggested as forming the marine boundary of this system. It was within this context that the present study was initiated.

Previous surveys of sublittoral benthos in surf-zone areas include Morgans (1962), Barnard (1963), McIntyre and Eleftheriou (1968), Corey (1970), Field (1971), Day et al. (1971), Masse (1971a, b, 1972), Christie (1976a), Hill and Hunter (1976), McLachlan et al. (1977), and Shin $(1981,1982)$. Of these only Day et al. (1971) Field (1971), and Christie (1976b) sampled quantitatively in true high energy surf zones. Field (1971) recognised an inner turbulent zone at 2 to $8 \mathrm{~m}$ depth and an outer turbulent zone at 16 to $23 \mathrm{~m}$ while Day et al. (1971) distinguished only a turbulent zone out to $20 \mathrm{~m}$. Christie (1976) recognised an inshore surf zone at 0 to $1 \mathrm{~m}$, an offshore surf zone at 3 to $5 \mathrm{~m}$ and an outer turbulent zone at 10 to $33 \mathrm{~m}$.

This study was designed to sample benthic macrofauna and meiofauna from inside the breakers to well beyond the surf zone off 3 beaches of differing exposure. The aims were to quantify abundance and biomass of metazoan benthos, to identify faunal assemblages associated with this turbulent zone and to ascertain whether the positions of the break point or outer limit of surf circulation cells could be linked to any sharp changes in seabed and benthic fauna.

\section{STUDY AREA}

Algoa Bay is a large 'half-heart' bay on the southeastern tip of Africa (Fig. 1). As swell mostly approaches from the south west and refracts into the bay, beaches increase in exposure from Cape Recife north-eastwards to Sundays River. All beaches do, however, have surf zones with continuous wave action. The beaches are composed of fine to medium quartz sands and have moderate to rich benthic faunas dominated by molluscs (McLachlan, 1977). Surf zones range from 50 to $500 \mathrm{~m}$ wide in different areas under different 
conditions. Mean spring tide range is $1.65 \mathrm{~m}$ with a maximum of $2.1 \mathrm{~m}$.

The 3 surf zones selected for study were off Kings Beach, Blue Water Bay beach and Sundays River beach in order of increasing exposure. Profiles of their sublittoral areas as determined by SCUBA transects are given in Fig. 1. On Kings Beach breaking waves average about $1 \mathrm{~m}$ height and break 50 to $100 \mathrm{~m}$ from the shore. Some flat rocky reefs occur a little way offshore. Corresponding figures for Blue Water Bay are 1.5 to $2 \mathrm{~m}$ waves and a 100 to $150 \mathrm{~m}$ surf zone and for Sundays River 2 to $4 \mathrm{~m}$ waves and a 200 to $300 \mathrm{~m}$ surf zone.

\section{METHODS}

Stations were sampled along transects off each beach using SCUBA. Depth was determined with a depth gauge and echo sounder and corrected for state of tide to get depth below LWS. At each station 5 cores $30 \mathrm{~cm} \times 10 \mathrm{~cm}^{2}$ were taken in PVC tubes and later cut into $3 \times 10 \mathrm{~cm}$ sections representing 3 depth layers. Four were kept for meiofauna extraction and 1 for physical and chemical analysis.

Macrofauna was sampled in 2 ways: (1) by dredging roughly 5 to $8 \mathrm{~m}^{2}$ using a diver-controlled dredge $33 \mathrm{~cm}$ wide and with $5 \mathrm{~mm}$ mesh to collect large mobile forms; (2) by using a diver-operated suction sampler modified from Christie and Allen (1972). This sampled an area of $0.1 \mathrm{~m}^{2}$ to $50 \mathrm{~cm}$, the sand being passed through a $1 \mathrm{~mm}$ mesh collecting basket to trap the macrofauna. As Christie (1976b) found that 3 replicate samples were sufficient to trap $88 \%$ of the common species in a similar environment, this number of samples was taken at each station.

Meiofauna were relaxed in $7 \% \mathrm{Mg} \mathrm{Cl}_{2}$, fixed in $10 \%$ formalin, extracted by 4 decants through a $45 \mu \mathrm{m}$ screen and stained with rose bengal. Taxa were counted under a stereomicroscope and counts multiplied by 1.1 to correct for $90 \%$ extraction efficiency. Biomass was calculated from mean individual mass estimates for the dominant taxa (McLachlan, 1977). Macrofauna samples were preserved in $10 \%$ formalin, all species identified and dry biomass determined by drying at $70^{\circ} \mathrm{C}$.

From each $10 \mathrm{~cm}$ depth layer a $50 \mathrm{~g}$ sand sample was wet-sieved through a series of screens at $0.5 \varnothing$ intervals and the usual parameters calculated. A $20 \mathrm{~g} \mathrm{sam-}$ ple was analysed for $\mathrm{CaCO}_{3}$ by acid treatment. A $2 \mathrm{~g}$ sample was dried at $90^{\circ} \mathrm{C}$ and ashed at $500^{\circ} \mathrm{C}$ for $6 \mathrm{~h}$ to estimate organic content. A $2 \mathrm{~g}$ sample was also analysed by the microkjeldahl method for nitrogen.

All sedimentary and faunal data were compared by cross correlation using linear regression. Macrofaunal stations were subjected to numerical classification using the Bray-Curtis similarity coefficient and group average clustering based on log transformed data (Clifford and Stepenson, 1975; Field et al., 1982). In addition the similarity data were ordinated by multidimensional scaling (Orloci, 1978; Field et al., 1982).

\section{RESULTS}

Profiles of the 3 transects are shown in Fig. 1, and Table 1 summarises the sedimentary parameters. With a few exceptions all stations had fine to medium quartz sands with high calcium carbonate contents. The coarser inshore samples generally had lower subsieve and higher $\mathrm{CaCO}_{3}$ contents. At Blue Water Bay, Stations $4,6,8$ and $10 \mathrm{~m}$ had coarse gravel substrates and no samples were taken. At Sundays River, Stations 13 15 and $20 \mathrm{~m}$ had high subsieve fractions and low $\mathrm{CaCO}_{3}$ contents. At $13 \mathrm{~m}$ and $15 \mathrm{~m}$ at Sundays River layers of fine and coarser material gave trimodal and bimodal particle size structures. Organic contents

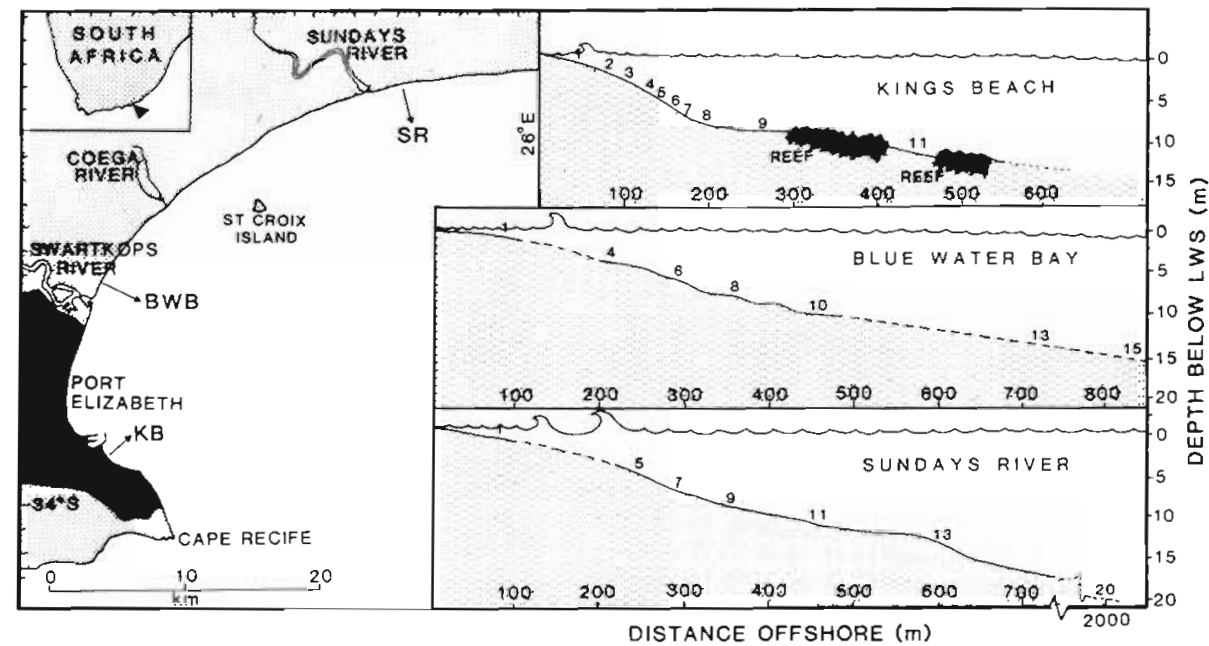

Fig. 1. Study area showing profiles of the 3 transects and sampling stations 
Table 1. Summary of sediment parameters. All values on a dry mass basis. $\mathrm{Md}=$ median particle diameter; $\mathrm{MZ}=$ mean particle diameter

\begin{tabular}{|c|c|c|c|c|c|c|c|}
\hline \multirow{2}{*}{ Station } & \multicolumn{2}{|c|}{ Particle size } & \multirow{2}{*}{$\begin{array}{c}<62 \mu \mathrm{m} \\
\% \text { subsieves }\end{array}$} & \multirow{2}{*}{$\begin{array}{c}\% \\
\mathrm{CaCO}_{3}\end{array}$} & \multirow{2}{*}{$\begin{array}{c}\% \\
\text { organics }\end{array}$} & \multirow{2}{*}{$\begin{array}{l}\mathrm{N}\left(\mathrm{mg} \mathrm{g}^{-1}\right. \\
\text { sand) }\end{array}$} & \multirow[t]{2}{*}{ Remarks } \\
\hline & $\mathrm{Md}(\mu \mathrm{m})$ & $M Z(\mu \mathrm{m})$ & & & & & \\
\hline KB 1 & 243 & 238 & 2.5 & 38 & 1.77 & 0.23 & Well sorted, fine sand \\
\hline KB 2 & 277 & 279 & 3.5 & 25 & 2.37 & 0.26 & Well sorted, medium sand \\
\hline $\mathrm{KB} 3$ & 222 & 226 & 3.8 & 40 & 1.64 & 0.19 & Well sorted, fine sand \\
\hline KB 4 & 226 & 227 & 4.4 & 42 & 2.01 & 0.12 & Well sorted, fine sand \\
\hline KB 5 & 205 & 206 & 4.0 & 38 & 2.63 & 0.25 & Well sorted, fine sand \\
\hline KB 6 & 209 & 209 & 3.6 & 40 & 1.80 & 0.26 & Well sorted, fine sand \\
\hline $\mathrm{KB} 7$ & 190 & 198 & 6.9 & 25 & 3.41 & 0.41 & Well sorted, fine sand \\
\hline KB 8 & 197 & 199 & 3.2 & 45 & 1.68 & 0.21 & Well sorted, fine sand \\
\hline KB 9 & 161 & 193 & 6.7 & 43 & 2.68 & 0.33 & Moderately sorted, fine sand \\
\hline KB 11 & 205 & 204 & 3.2 & 57 & 1.38 & 0.16 & Well sorted, fine sand \\
\hline BWB 1 & 216 & 217 & 2.4 & 40 & 1.78 & 0.09 & Well sorted, fine sand \\
\hline BWB 13 & 207 & 245 & 9.0 & 43 & 1.87 & 0.25 & Poorly sorted, fine sand \\
\hline BWB 15 & 235 & 234 & 6.8 & 43 & 2.29 & 0.14 & Well sorted, fine sand \\
\hline SR 1 & 239 & 235 & 2.4 & 35 & 1.02 & 0.09 & Well sorted, fine sand \\
\hline SR 5 & 229 & 224 & 3.2 & 36 & 1.40 & 0.07 & Well sorted, fine sand \\
\hline SR 7 & 144 & 149 & 10.8 & 35 & 1.66 & 0.12 & Poorly sorted, fine sand \\
\hline SR 9 & 177 & 184 & 2.5 & 37 & 1.76 & 0.11 & Well sorted, fine sand \\
\hline SR 11 & 183 & 182 & 6.7 & 31 & 1.79 & 0.20 & Well sorted, fine sand \\
\hline SR 13 & 154 & 143 & 8.5 & 20 & 1.89 & 0.28 & $\begin{array}{l}\text { Trimodal, modes at } 200,150 \\
\text { and } 70 \mu \mathrm{m}\end{array}$ \\
\hline SR 15 & 110 & 101 & 15.2 & 9 & 1.60 & 0.12 & Bimodal, modes at 150 and $70 \mu \mathrm{m}$ \\
\hline SR 20 & 86 & - & 26.5 & 11 & 1.76 & 0.13 & Very fine sand, moderately sorted \\
\hline
\end{tabular}

ranged 1.02 to $3.41 \%$ and nitrogen 0.07 to $0.41 \%$, both increasing offshore and in finer sediments.

Linear regression analysis showed the percentage of subsieve particles to be negatively correlated with mean particle diameter $\left(\mathrm{M}_{z} \mu \mathrm{m}\right)(\mathrm{r}=0.86, \mathrm{p}<0.001)$ while $\mathrm{CaCO}_{3}$ levels were positively correlated with the mean particle diameter $(\mathrm{r}=0.79, \mathrm{p}<0.001)$. Calcium carbonate and subsieve levels were negatively correlated $(\mathrm{r}=0.77, \mathrm{p}<0.001)$. Levels of organics and nitrogen were positively correlated (Fig. 2).

Meiofauna abundance and biomass figures are summarised in Table 2. Biomass estimates are based on the following mean individual dry mass values (McLachlan, 1977): nematodes $0.5 \mu \mathrm{g}$, harpacticoids $0.4 \mu \mathrm{g}$,

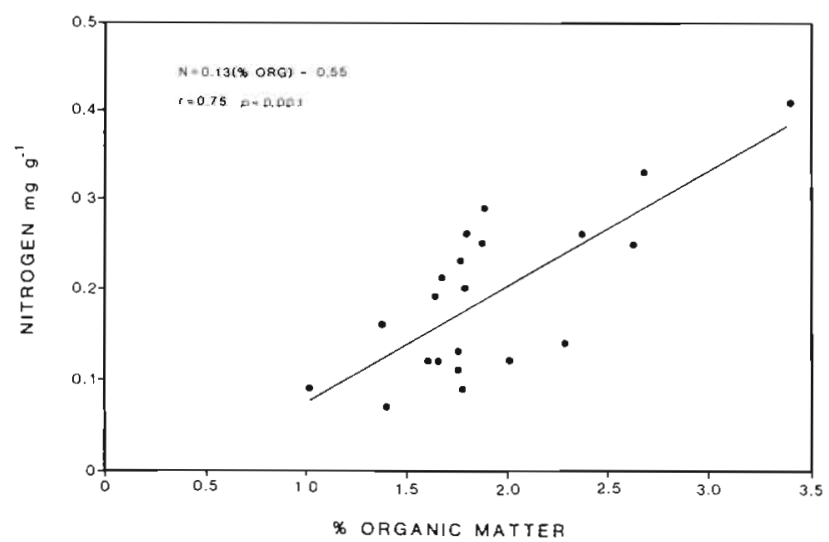

Fig. 2. Relationship between nitrogen and organic matter in sediments turbellarians $0.5 \mu \mathrm{g}$, annelids $1.6 \mu \mathrm{g}$, and others $1.0 \mu \mathrm{g}$. Nematodes dominated all stations except KB 1 and SR 1 where turbellarians and oligochaetes dominated respectively. The hydrodynamic forces in both these areas appear to select for large body size. Harpacticoids were surprisingly low in abundance, making up less than $10 \%$ of meiofauna numbers at most stations. The meiofauna was mostly not concentrated in the surface layers and in several cases numbers in the 20 to $30 \mathrm{~cm}$ layer were similar to or even greater than those in the 0 to $10 \mathrm{~cm}$ layer. The biomass range recorded, 72 to $1098 \mathrm{mg} \mathrm{m}^{2}$, may therefore represent only about 50 to $90 \%$ of total meiofauna biomass.

Though there were no significant correlations between numbers of nematodes and harpacticoids and sand particle size, significant correlations were obtained between levels of organic materials and nitrogen in the sand and the abundance of certain taxa and total biomass (Table 3). Numbers and biomass increased with increasing organic and nitrogen content of the sand in all cases.

Macrofauna species abundance, total biomass and the partitioning of biomass into taxa and feeding categories are shown in Table 4. A total of 98 species was recorded, many of these being new distribution records for this area. Species numbers increased with depth along all transects. Crustaceans, molluscs and echinoderms dominated biomass. Although polychaetes were always present they did not attain high biomass values. Total dry biomass ranged from 4 
Table 2. Meiofaunal abundance, composition and biomass in the top $30 \mathrm{~cm}$ sediment. $\mathrm{N}=$ nematodes, $H=$ harpacticoids, $T=$ turbellarians, $\mathrm{A}=$ annelids, $\mathrm{O}=$ others. $\frac{20-30}{0-10} \%$ : numbers in the 20 to $30 \mathrm{~cm}$ layer as percentage of those in the 0 to $10 \mathrm{~cm}$ layer

\begin{tabular}{|c|c|c|c|c|c|c|c|c|}
\hline Station & $\begin{array}{l}\text { Abundance } \\
\left(\text { No. } 10 \mathrm{~cm}^{-2}\right)\end{array}$ & $\% N$ & $\% \mathrm{H}$ & $\begin{array}{c}\text { Composition } \\
\% \mathrm{~T}\end{array}$ & $\% \mathrm{~A}$ & $\% \mathrm{O}$ & $\frac{20-30}{0-10} \%$ & $\begin{array}{c}\text { Biomass } \\
\left(\mathrm{mg} \mathrm{m}^{-2}\right) \mathrm{dry}\end{array}$ \\
\hline $\mathrm{KB} 1$ & 656 & 35 & 14 & 48 & $<1$ & 3 & 71 & 333 \\
\hline $\mathrm{KB} 2$ & 1362 & 79 & 14 & 5 & 2 & $<1$ & 36 & 689 \\
\hline $\mathrm{KB} 3$ & 1333 & 82 & 4 & 7 & 6 & 1 & 51 & 752 \\
\hline $\mathrm{KB} 4$ & 1451 & 80 & 5 & 6 & 9 & $<1$ & 45 & 858 \\
\hline $\mathrm{KB} 5$ & 1447 & 90 & 4 & 4 & 1 & 1 & 107 & 734 \\
\hline KB 6 & 1736 & 86 & 5 & 8 & $<1$ & $<1$ & 99 & 871 \\
\hline $\mathrm{KB} 7$ & 2201 & 88 & 4 & 8 & 0 & $<1$ & 71 & 1098 \\
\hline KB 8 & 1042 & 88 & 3 & 8 & $<1$ & $<1$ & 56 & 522 \\
\hline $\mathrm{KB} 9$ & 1608 & 94 & $<1$ & 5 & 0 & $<1$ & 12 & 806 \\
\hline KB 11 & 462 & 85 & 6 & 8 & 0 & 1 & 171 & 230 \\
\hline BWB 1 & 701 & 77 & 1 & 6 & $<1$ & 16 & 11 & 408 \\
\hline BWB 13 & 347 & 95 & 1 & 1 & 0 & 3 & 13 & 178 \\
\hline BWB 15 & 1026 & 94 & 0 & 4 & $<1$ & 2 & 99 & 523 \\
\hline SR 1 & 908 & 44 & 5 & 2 & 49 & $<1$ & 16 & 938 \\
\hline SR 5 & 612 & 92 & 1 & 6 & 0 & 1 & 37 & 309 \\
\hline SR 7 & 937 & 90 & 2 & 7 & 0 & 1 & 21 & 465 \\
\hline SR 9 & 576 & 93 & $<1$ & 5 & 0 & $<1$ & 68 & 290 \\
\hline SR 11 & 887 & 93 & 1 & 6 & 0 & 1 & 39 & 446 \\
\hline SR 13 & 1422 & 73 & 18 & 8 & 0 & 1 & 9 & 691 \\
\hline SR 15 & 479 & 97 & 1 & 2 & 0 & 0 & 9 & 239 \\
\hline SR 20 & 144 & 100 & 0 & 0 & 0 & 0 & 74 & 72 \\
\hline
\end{tabular}

Table 3. Summary of significant correlations between meiofauna and sediment parameters

\begin{tabular}{|lllll}
\hline \multicolumn{1}{c}{$\mathrm{X}$} & \multicolumn{1}{c}{$\mathrm{Y}$} & $\mathrm{r}$ & $\mathrm{P}$ \\
\hline \% organics & Nerratode nos $\left(10 \mathrm{~cm}^{-2}\right)$ & $\mathrm{Y}=679 \mathrm{X}-455$ & 0.75 & $<0.001$ \\
\% organics & Biomass $\left(\mathrm{mg} \mathrm{m} \mathrm{m}^{-2}\right)$ & $\mathrm{Y}=256 \mathrm{X}+55$ & 0.47 & $<0.05$ \\
Nitrogen $\left(\mathrm{mg} \mathrm{g}^{-1}\right)$ & Nematode nos $\left(10 \mathrm{~cm}^{-2}\right)$ & $\mathrm{Y}=3606 \mathrm{X}+153$ & 0.69 & $<0.01$ \\
Nitrogen $\left(\mathrm{mg} \mathrm{g}^{-1}\right)$ & Harpacticoid nos $\left(10 \mathrm{~cm}^{-2}\right)$ & $\mathrm{Y}=343 \mathrm{X}+15$ & 0.47 & $<0.05$ \\
Nitrogen $\left(\mathrm{mg} \mathrm{g}^{-1}\right)$ & Turbellarian nos $\left(10 \mathrm{~cm}^{-2}\right)$ & $\mathrm{Y}=412 \mathrm{X}-4$ & 0.53 & $<0.01$ \\
Nitrogen $\left(\mathrm{mg} \mathrm{g}^{-1}\right)$ & Biomass $\left(\mathrm{mg} \mathrm{m}^{-2}\right)$ & $\mathrm{Y}=1581 \mathrm{X}+242$ & 0.50 & $<0.05$ \\
\hline
\end{tabular}

$\mathrm{mg} \mathrm{m}^{-2}$ (BWB 8) to $15397 \mathrm{~g} \mathrm{~m}^{-2}$ (SR 20), generally increasing with depth along all three transects. Except for the shallowest stations, suspension feeders made up a small proportion of biomass. Deposit feeders dominated most deeper stations while predator/ scavengers were always abundant and often dominated at intermediate depths.

Cross correlation of all macrofauna and sedimentary parameters yielded several significant regressions (Table 5). The biomass of most macrofaunal groups was positively correlated with levels of organics and subsieves and negatively correlated with particle size over the range sampled. There was no correlation between the biomass of suspension feeders and that of deposit feeders and both decreased with increasing particle size. Over this range of the environmental gradient all groups increase in biomass as turbulence decreases. This overriding gradient of turbulence probably marks other interactions which might become clearer further offshore where turbulence is less. Water movement in the form of turbulence therefore appears to be the 'super-parameter' determining macrobenthic community structure in these high energy nearshore zones. Communities become more diverse and attain higher biomass values as the turbulence gradient is descended offshore.

Total biomass was calculated for a metre-wide transect from the beach out through the surf zone off Kings and Sundays River beaches. This gives an estimate of $4500 \mathrm{~g} \mathrm{~m}^{-1}$ out to $10 \mathrm{~m}$ at Kings Beach and $12250 \mathrm{~g} \mathrm{~m}^{-1}$ out to $20 \mathrm{~m}$ at Sundays River beach.

Because of the very coarse substrates and sparse fauna, stations along the Blue Water Bay transect showed very little similarity to each other or to stations along the other two transects. The Blue Water Bay stations have therefore been left out of the dendrograms depicting macrofaunal similarities between stations (Fig. 3) and only the Kings Beach and Sundays 
Fig. 3. Dendrograms showing similarities between macrofaunal stations along 2 transects
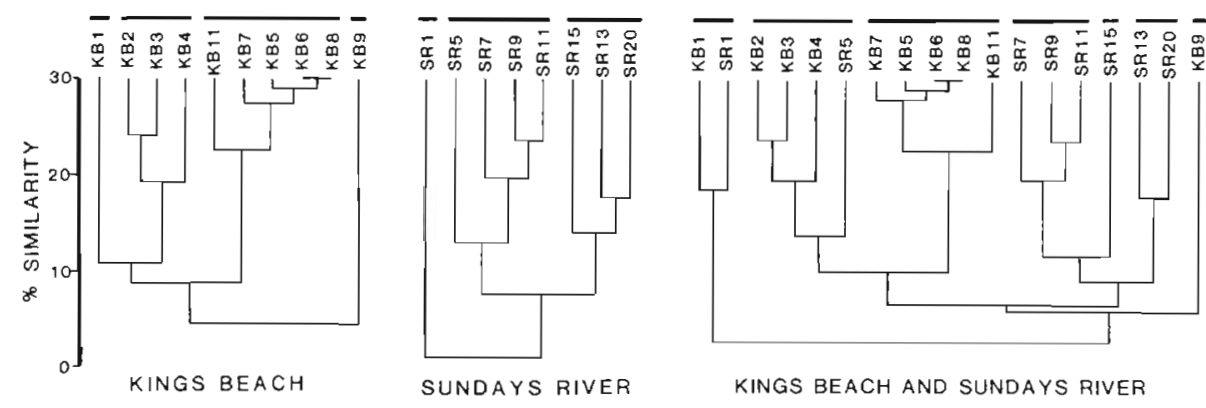

KINGS BEACH AND SUNDAYS RIVER
River transects will be considered in terms of faunal associations. The Kings Beach stations group into 4 associations, $1 \mathrm{~m}, 2$ to $4 \mathrm{~m}, 5$ to 11 , and $9 \mathrm{~m}$. As the latter station had an unusually high silt content it is perhaps best ignored. This leaves 3 associations, $1 \mathrm{~m}$ in the breaker zone, 2 to $4 \mathrm{~m}$ just outside the breakers, and 5 to $11 \mathrm{~m}$ in deeper water. Sundays River produces a similar pattern with 3 groupings, $1 \mathrm{~m}$ inside the breakers, 5 to $11 \mathrm{~m}$ just outside the breakers, and 13 to $20 \mathrm{~m}$ further out. When the Kings Beach and Sundays River stations are combined the presence of 3 main groups of stations is still strongly suggested. The two 1 $m$ stations inside the breakers or surf zone group together as do the stations just outside the breakers, KB 2 to $4 \mathrm{~m}$ and SR $5 \mathrm{~m}$. However, the SR 7 to $11 \mathrm{~m}$ stations remain separate. The deeper stations, KB 5 to 11 and SR 13 to 20 also remain separate. The fact that the deeper stations at Kings Beach do not group with the deeper stations at Sundays River is probably due to the finer substrates and high silt content of the latter, this being due to the proximity of the river mouth, a source of silt during flooding.

Fig. 3 suggests that while the stations just outside the breakers at Kings Beach (2 to $4 \mathrm{~m}$ ) group closely together, this grouping is less clear at Sundays River where the $5 \mathrm{~m}$ station is more closely related to the Kings Beach stations than to its 7 to $11 \mathrm{~m}$ stations. Fig. 4 depicts relations between macrofaunal stations after multi-dimensional scaling of the similarity matrix and arranges the stations along a gradient of increasing turbulence.

The shallowest stations inside the breakers had very low biomass values and diversity and were dominated by Donax sordidus. Gastrosaccus psammodytes, Macropetasma africanus and Bullia spp. also occurred. The stations just outside the breakers also had low biomass and were characterised by the presence of $D$. sordidus as well as some species which reached greater abundance further offshore, e.g. Nephtys capensis, Goniadopsis incerta. Numbers and diversity were still low and no species were restricted to this area. This therefore appears to be a transition area between surf zone and deeper associations. The third group starts

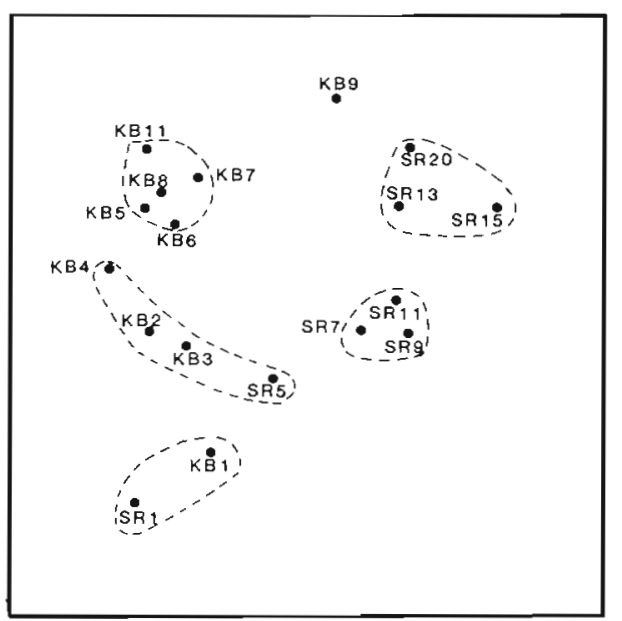

Fig. 4. Ordination of macrofaunal stations based on multidimensional scaling of the similarity matrix

where the bottom becomes more stable and is marked by a rapid rise in diversity and biomass. At Kings Beach this starts sharply at $5 \mathrm{~m}$ while at Sundays River it is less abrupt, starting at 11 to $13 \mathrm{~m}$. Off Kings Beach Callianassa spp. and Echinocardium cordatum are dominant elements of this association while at Sundays River Golfingia capensis, Phaxas decipiens and aplacophoran molluscs are dominant. Therefore, although both of these associations occur in the outer turbulent zone, different sediment conditions result in different community compositions. Fig. 5 and 6 depict the distributions of biomass, species numbers, sand particle size and dominant species along these 2 transects. The trough in biomass and diversity around the break point as well as the rapid increase in both again a little way beyond the breakers can clearly be seen for both beaches. Estimates of the partitioning of Macrofauna biomass among these associations are as follows: (1) From LWS to the break point $-5 \mathrm{~g} \mathrm{~m}^{-1}$ at Kings Beach and $30 \mathrm{~g} \mathrm{~m}^{-1}$ at Sundays river; (2) from the break point to the end of the transition zone $-290 \mathrm{~g}$ $\mathrm{m}^{-1}$ and $340 \mathrm{~g} \mathrm{~m}^{-1}$ respectively; (3) from the end of the transition zone to $10 \mathrm{~m}$ and $20 \mathrm{~m}-4200 \mathrm{~g} \mathrm{~m}^{-1}$ and $11880 \mathrm{~g} \mathrm{~m}^{-1}$ respectively. 


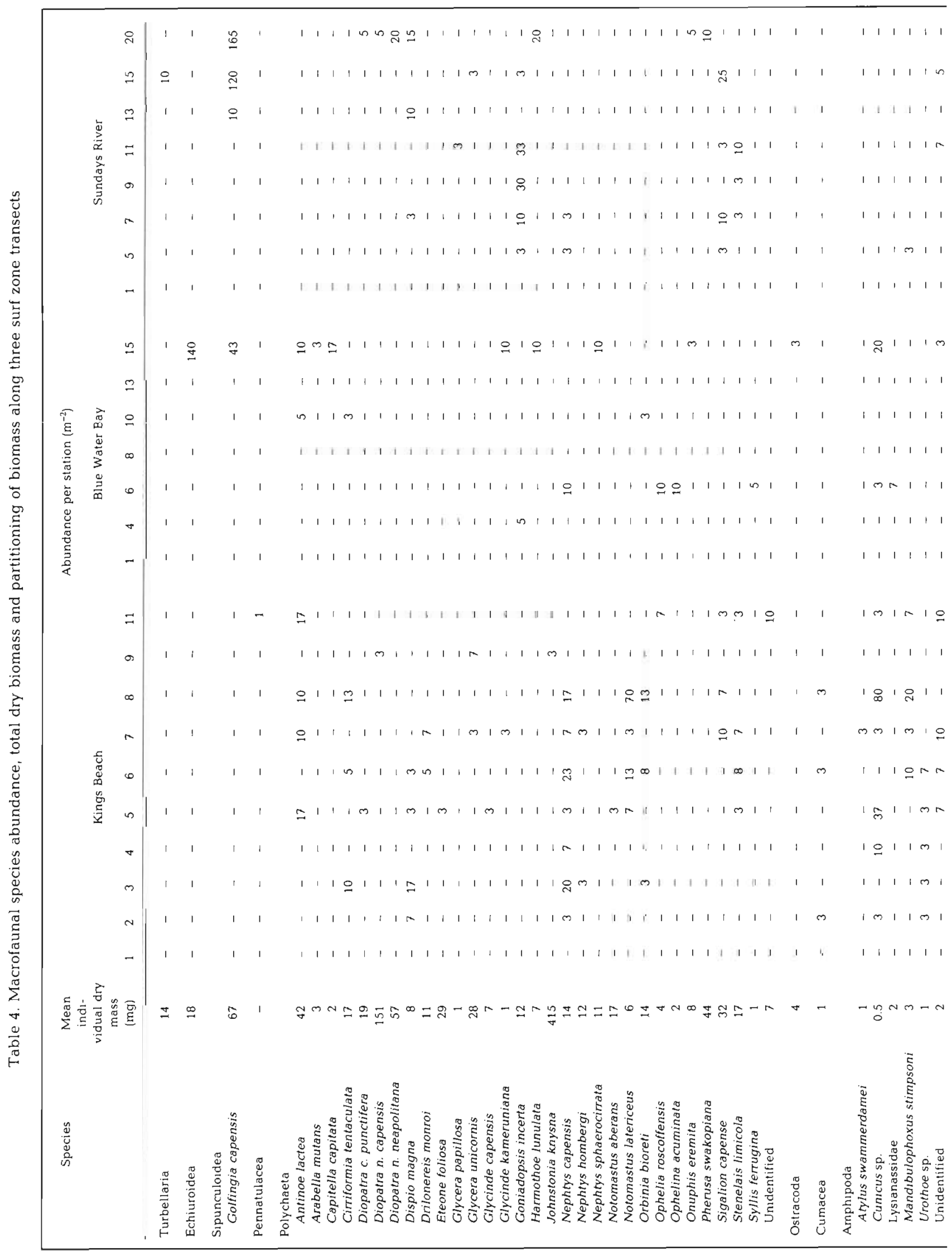




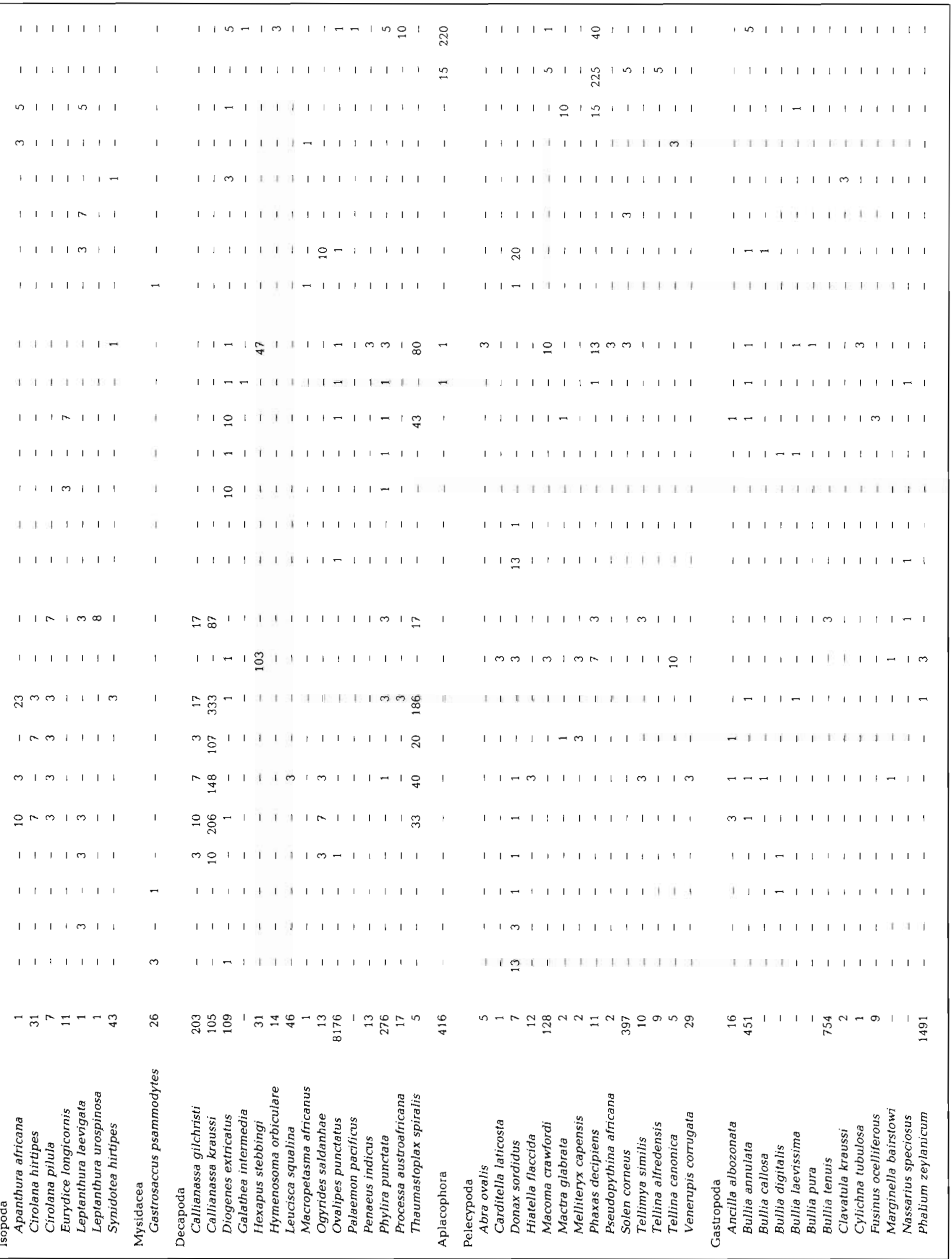




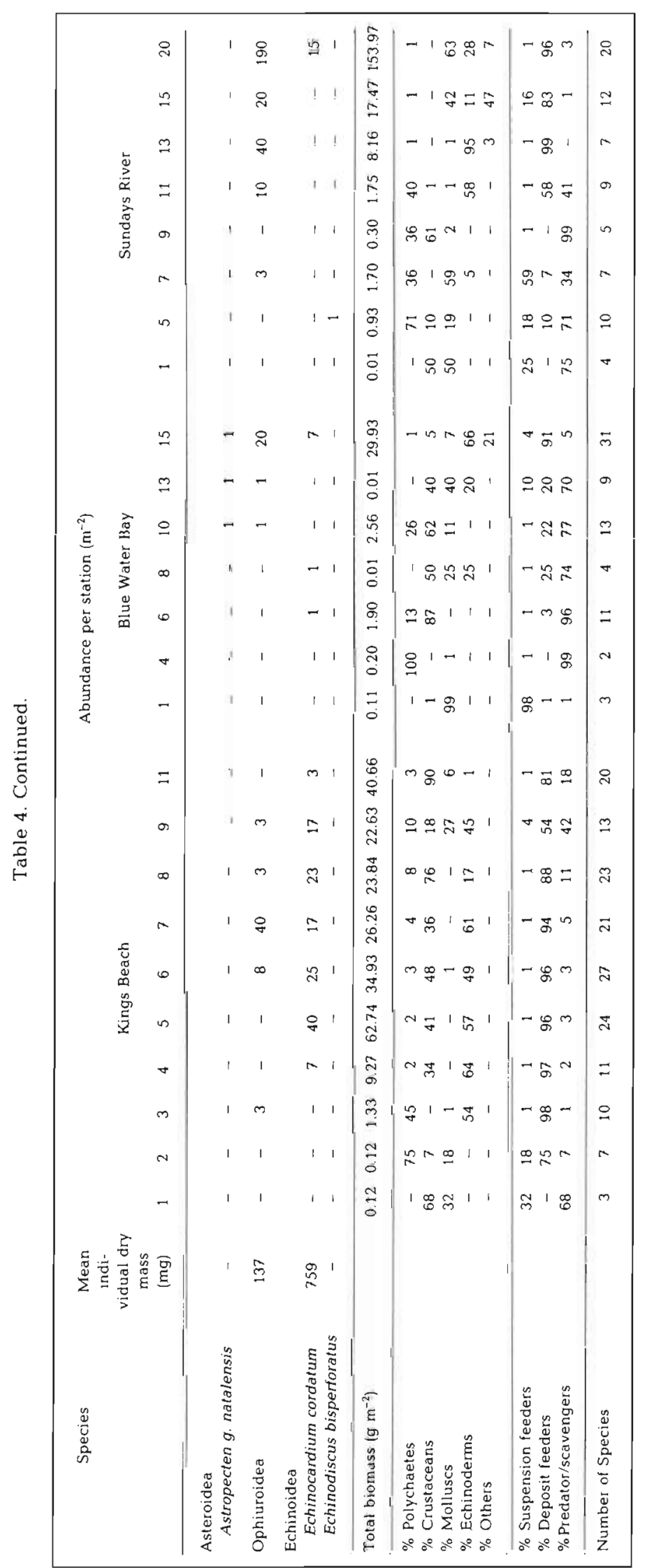


Table 5. Summary of significant correlations between macrofauna and sediment parameters

\begin{tabular}{|c|c|c|c|c|}
\hline $\mathrm{x}$ & $\mathrm{Y}$ & Equation & I & $\mathbf{P}$ \\
\hline$\%$ organics & Echinoderm biomass $\left(\mathrm{mg} \mathrm{m}^{-2}\right)$ & $Y=18964$ in $X-1577$ & 0.55 & $<0.01$ \\
\hline$\%$ organics & Predator biomass ( $\mathrm{mg} \mathrm{m}^{-2}$ ) & $Y=16001 \mathrm{n} X-62$ & 0.47 & $<0.05$ \\
\hline$M Z(\mu \mathrm{m})$ & Mollusc biomass ( $\mathrm{mg} \mathrm{m}^{-2}$ ) & $Y=269982-50267$ 1n $X$ & 0.68 & $<0.001$ \\
\hline$M Z(\mu \mathrm{m})$ & Suspension feeder $\left(\mathrm{mg} \mathrm{m}^{-2}\right)$ & $Y=2487-10.6 X$ & 0.69 & $<0.001$ \\
\hline$M Z(\mu \mathrm{m})$ & Deposit feeder biomass ( $\mathrm{mg} \mathrm{m}^{-2}$ ) & $Y=94020-378 X$ & 0.52 & $<0.05$ \\
\hline $\mathrm{MZ}(\mu \mathrm{m})$ & Total biomass ( $\mathrm{mg} \mathrm{m}^{-2}$ ) & $Y=399931-72087 X$ & 0.59 & $<0.01$ \\
\hline$\%$ subsieves & Polychaete biomass $\left(\mathrm{mg} \mathrm{m}^{-2}\right)$ & $Y=151+3731 \mathrm{n} X$ & 0.47 & $<0.05$ \\
\hline$\%$ subsieves & Mollusc biomass ( $\mathrm{mg} \mathrm{m}^{-2}$ ) & $Y=3261 X-15189$ & 0.81 & $<0.001$ \\
\hline$\%$ subsieves & Echinoderm biomass $\left(\mathrm{mg} \mathrm{m}^{-2}\right)$ & $Y=106+1205 X$ & 0.52 & $<0.05$ \\
\hline$\%$ subsieves & Suspension feeder biomass $\left(\mathrm{mg} \mathrm{m}^{-2}\right)$ & $Y=101 X-259$ & 0.75 & $<0.001$ \\
\hline$\%$ subsieves & Deposit feeder biomass ( $\mathrm{mg} \mathrm{m} \mathrm{m}^{-2}$ ) & $Y=4313 X-8627$ & 0.68 & $<0.001$ \\
\hline$\%$ subsieves & Total biomass ( $\mathrm{mg} \mathrm{m}^{-2}$ ) & $Y=4498 X-7885$ & 0.68 & $<0.001$ \\
\hline
\end{tabular}

Fig. 5. Some gradients along a transect off Kings Beach, including distribution of dominant species

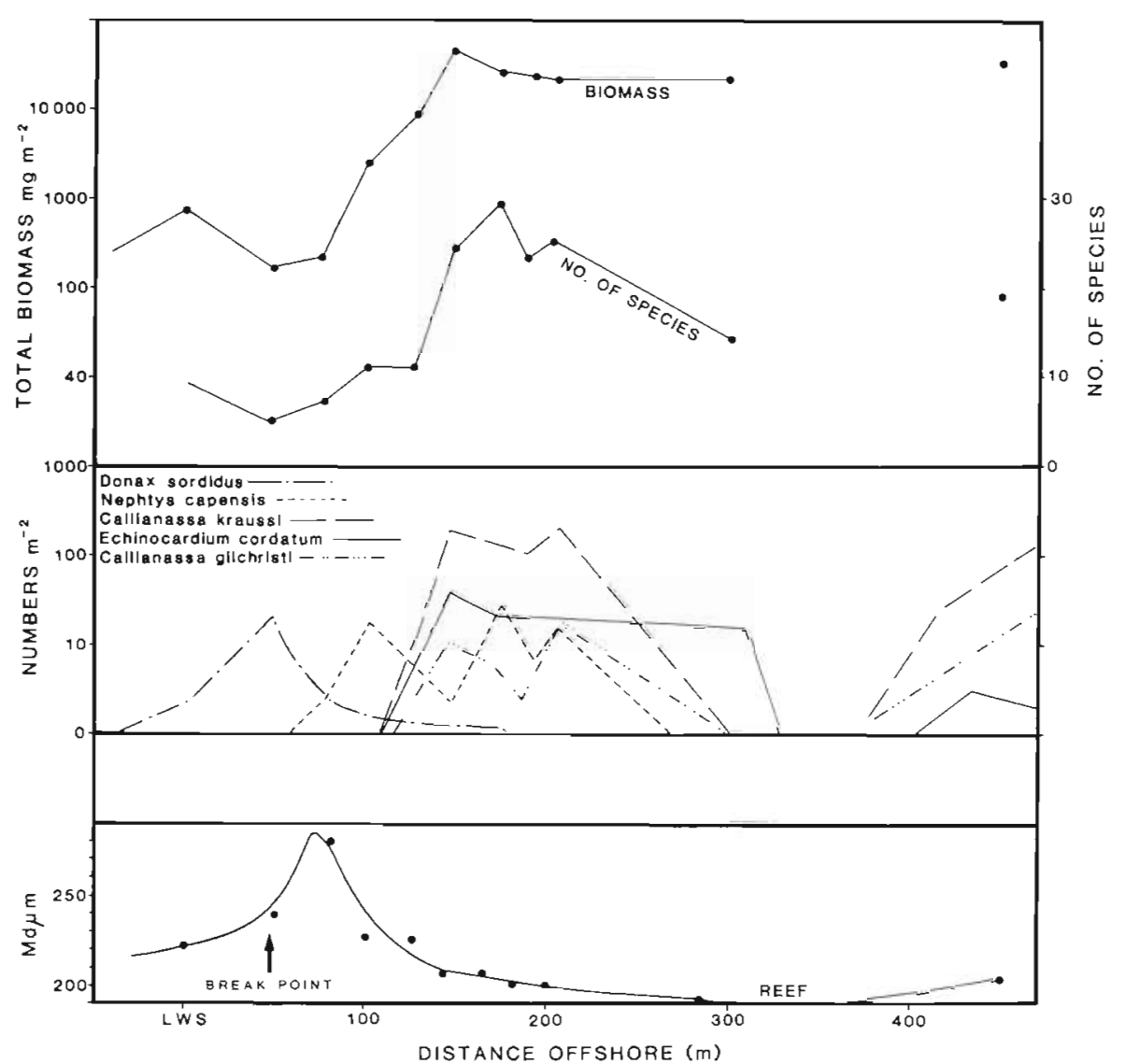

\section{DISCUSSION}

Of the 3 transect lines sampled, Kings Beach and Sundays River showed relatively even gradients of sedimentary change in response to the wave induced turbulence gradient. Coarsest sand occurred around the break point and sand became slightly finer towards the beach and steadily finer and with more subsieve particles further offshore. The Blue Water Bay line contained several gravel patches at intermediate depths and therefore cannot be considered as typical of the gradient through a high energy surf zone. It must be expected when evaluating distribution patterns along such a gradient that sediment type will cause local modifications on the more general depth zonation pattern (Field, 1971). In further discussion, however, only the Kings Beach and Sundays River stations will be referred to. 


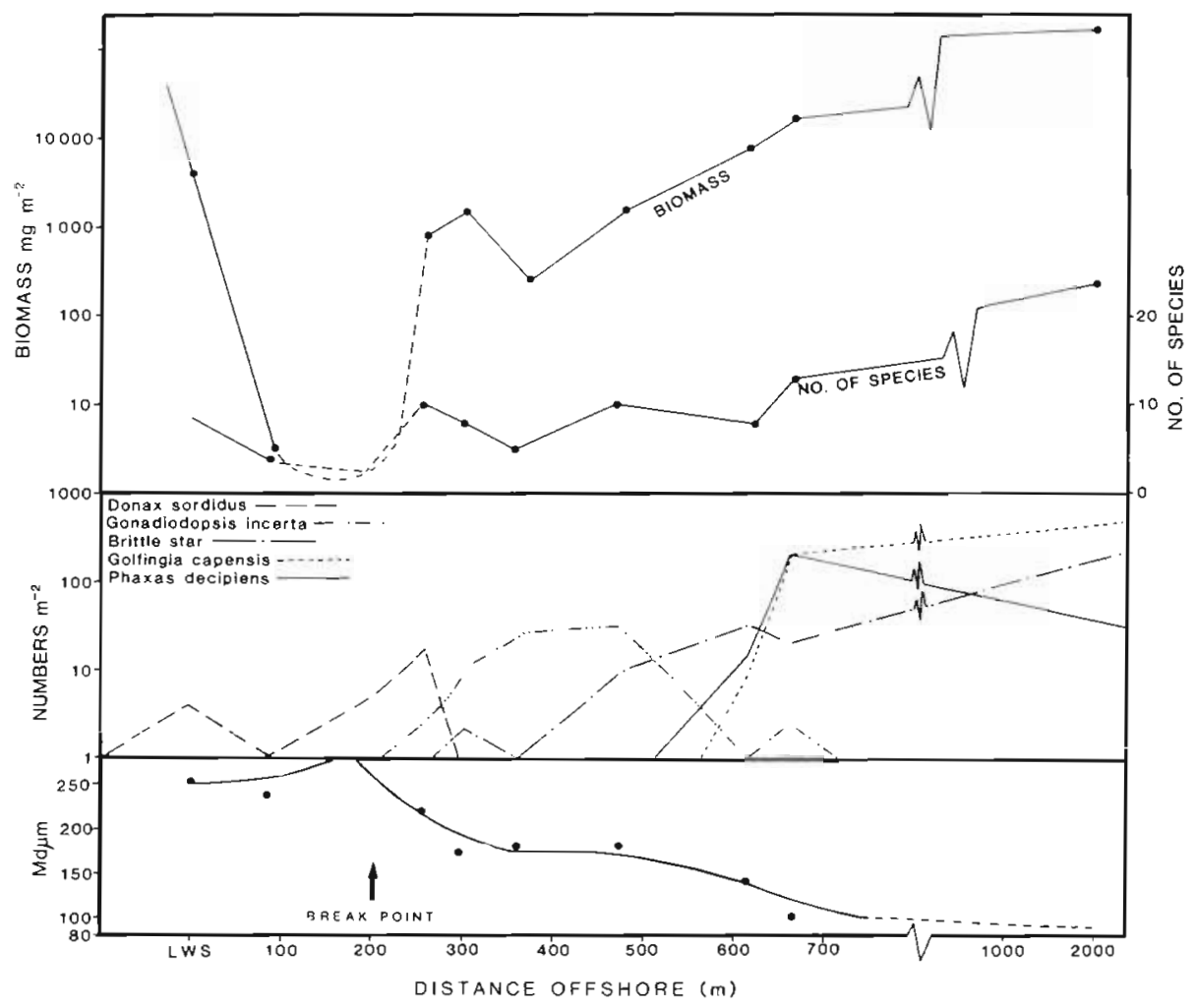

Fig. 6. Some gradients along a transect off Sundays River beach, including distribution of dominant species

Meiofauna numbers $\left(0.1\right.$ to $\left.2.2 \times 10^{6} \mathrm{~m}^{-2}\right)$ were close to the average of $10^{6} \mathrm{~m}^{-2}$ for soft sediments and similar to values recorded at 5 to $50 \mathrm{~m}$ depth in this area (McLachlan et al., 1977). As a significant proportion of the meiofauna was missed by not sampling deeper into the sediment, actual numbers may be up to $50 \%$ higher at some stations. The proportion of harpacticoids was low in comparison with other findings for shallow sands (Coull, 1970; Thomassin et al., 1976) even in this area (McLachlan et al., 1977).

Meiofauna biomass can be calculated for metrewide transects at Kings Beach and Sundays River by multiplying biomass $\mathrm{m}^{-2}$ by distance in each transect zone and can be compared with the values for the macrofauna. In the 3 zones - surf, transition zone and outer turbulent zone - meiofauna biomass was $32 \mathrm{~g}$ $\mathrm{m}^{-1}, 48 \mathrm{~g} \mathrm{~m}^{-1}$ and $148 \mathrm{~g} \mathrm{~m}^{-1}$ (total $228 \mathrm{~g} \mathrm{~m}^{-1}$ out to 10 $\mathrm{m})$ at Kings Beach, and $160 \mathrm{~g} \mathrm{~m}^{-1}, 103 \mathrm{~g} \mathrm{~m}^{-1}$ and $254 \mathrm{~g}$ $\mathrm{m}^{-1}$ (total $517 \mathrm{~g} \mathrm{~m}^{-1}$ out to $20 \mathrm{~m}$ ) at Sundays River. The ratios of macrofauna biomass/meiofauna biomass for these zones are 0.2, 6.0 and 28.4 at Kings Beach, and $0.2,3.3$ and 46.8 at Sundays River. Thus, passing down the turbulence gradient macrofauna increase considerably in importance relative to meiofauna. The relative stability and complexity of the interstitial system allows rich meiofaunas to develop even within the surf zone. Clearly the 3-dimensional habitat of the meiofauna is less sensitive to the 'physical control' (Sanders, 1968) of turbulence within the surf zone than the more 2-dimensional or superficial system of the macrofauna. While the macrofauna can only respond to high turbulence by becoming highly mobile, the interstitial fauna can penetrate deeper into the sediment as this is permitted by deeper oxygenation and water percolation as a result of wave pumping (Riedl et al., 1972). The macrofauna that do occur in this zone are all tough, motile forms which burrow superficially and undergo tidal migrations (McLachlan et al., 1979).

In the transition zone a change in dominance occurs and macrofauna begin to exceed the meiofauna in biomass. Towards the outer limits of this transition zone semi-permanent burrow formers appear, e.g. CaIlianassa spp. In this zone energy input to the bottom decreases over the range where a reasonable level of sediment stability starts. In the outer turbulent zone the well developed macrofauna community far exceeds the meiofauna in biomass. The point at which macrofauna biomass first exceeds meiofauna biomass is $3 \mathrm{~m}$ at Kings beach and $7 \mathrm{~m}$ at Sundays River, i.e. in the middle of the transition zone in both cases. The transition zone thus represents the area of rapid dropoff in wave energy reaching the bottom.

The macrofauna assemblages sampled here showed a clear increase in diversity and biomass offshore as recorded elsewhere (McIntyre and Eleftheriou, 1968; Day et al., 1971; Field, 1971; Masse, 1972; Christie, 1976a). Biomass (dry) in shallow sublittorial sands generally ranges from 1 to $50 \mathrm{~g} \mathrm{~m}^{-2}$ (McIntyre and Elef- 
theriou, 1968; Masse, 1972; Christie, 1976a). Biomass recorded in this study was generally 0 to $0.1 \mathrm{~g} \mathrm{~m}^{-2}$ in the surf zone, 1 to $10 \mathrm{~g} \mathrm{~m}^{-2}$ in the transition zone, and 10 to $150 \mathrm{~g} \mathrm{~m}^{-2}$ in the outer turbulent zone. Thus biomass within the surf zone is very reduced while in places in the outer turbulent zone it is very large. Where high biomass values (> $50 \mathrm{~g} \mathrm{~m}^{-2}$ ) occurred they were always due to deposit feeders in fine sediments. Under comparable circumstances Christie (1976a) recorded biomass values of 14 to $60 \mathrm{~g} \mathrm{~m}^{-2}$ in a transect through a high energy surf zone. He recorded maximum biomass at a depth of $5 \mathrm{~m}$, the same depth at which maximum biomass occurred off Kings Beach. This lies just outside the suggested transition zone. At both Kings Beach and Sundays River high sediment organic matter and macrofauna biomass levels at 5 and $13 \mathrm{~m}$ respectively (just outside the transition zones) suggest deposition of food particles kept in suspension in the shallower and more turbulent zones.

The general increase in total macrofauna biomass (as well as most component taxa and feeding groups) with decrease in sediment particle size and increasing subsieve particles and organic matter corresponds with Christie's (1976a) findings. He recorded an increase in both biomass and species richness offshore correlating with percentage clay in the sediment. The fact that both deposit and suspension feeders' biomass increased along the same gradient is in contrast to the trophic group amensalism hypothesis (Rhoads and Young, 1970). Even though suspension feeders normally dominate coarser sediments and deposit feeders finer sediments (Gray, 1981) the increase in both offshore supports Wildish's (1977) trophic group mutual exclusion hypothesis in the sense that water movement is the basic limiting factor and in the breaker region of high energy surf zones it even reaches limiting levels for suspension feeders on soft bottoms. As one moves away from this extreme physical condition, where great turbulence keeps the bottom almost free of macrofauna, the initial response is for all groups to increase. Presumably it is only when some degree of stability influences the bottom that biological interactions between deposit and suspension feeders may occur. The start of the outer turbulent zone may mark this point. Those macrofauna which do inhabit the most turbulent part of the surf zone are, however, all suspension feeders or predator/scavengers.

The 3 zones suggested here for sublittoral macrofauna of high energy sands agree very closely with the zones described by Christie (1976a). They may be coupled to ideas on intertidal zonation of macrofauna on high energy beaches to produce a single zonation scheme for the whole of the wave-controlled area of the sandy shoreline. Dahl (1952) first proposed 3 zones on sandy shores - a subterrestrial fringe occupied by ocypodid crabs in warm areas and talitrid amphipods in cold areas, a midlittoral zone characterized by cirolanid isopods, and a sublittoral fringe inhabited by many species. McLachlan (1980b) has employed this scheme on Algoa Bay beaches. Characteristic species of the sublittorial fringe are the clam Donax sordidus and the mysid Gastrosaccus psammodytes (McLachlan, $1980 \mathrm{a}, \mathrm{b})$. As these are also characteristic species of the surf zone (or inner turbulent zone) of this study there is clear correspondence between these zones.

If the sublittorial fringe and surf zone are considered the same then the following zonation scheme may be proposed (Fig. 7). The supralittorial zone is characterised by air breathing crustaceans; the midlittorial zone by cirolanid isopods; the inner turbulent zone (incorporating the sublittoral fringe and surf zone) by Gastrosaccus psammodytes and Donax sordidus; the transition zone includes both these and some species only becoming abundant further offshore; the outer turbulent zone is characterized by a number of species, differing in different substrates. Inhabitants of the midlittoral zone are intertidal species which may occasionally penetrate below tidemarks. Inhabitants of the inner turbulent zone are highly motıle subtidal species which may occasionally appear above tidemarks. The transition zone, with no 'endemic species' marks the area to which the break point might move during
Fig. 7. Diagrammatic representation of zonation of intertidal and sublittoral macrofauna on high energy sandy coasts

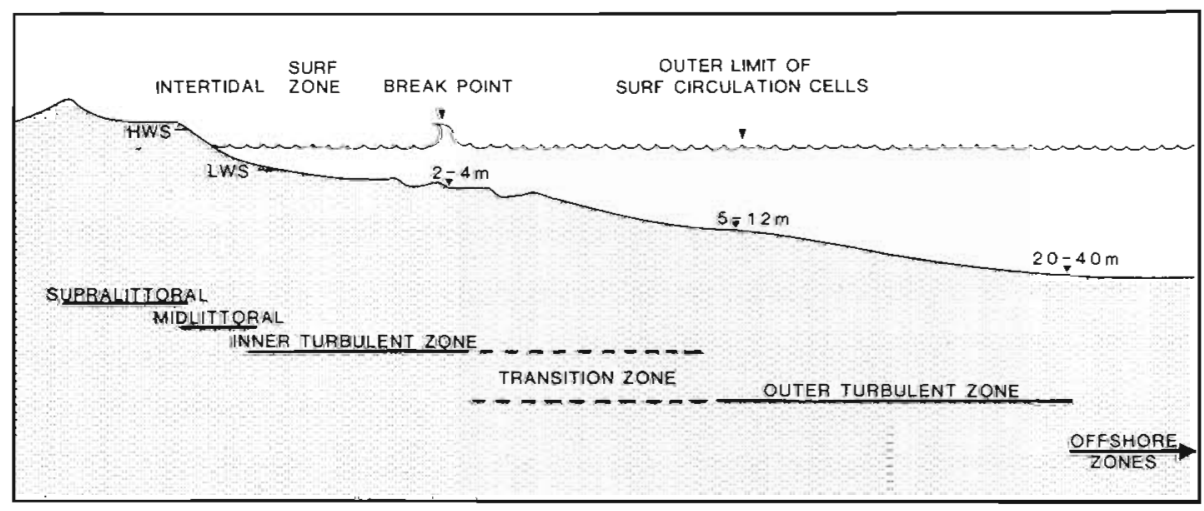


storms. It is also the zone in which stability of the bottom increases rapidly offshore. Its outer boundary appears to lie roughly near the outer limit of normal surf circulation cells, i.e. roughiy 2 to 3 times the width of the breaker zone from the beach (Inman and Brush, 1973; Harris, 1978). The outer turbulent zones is marked by a sudden increase in diversity and biomass as the bottom stabilises, although wave energy is still important. Dominant species may be Callianiassa spp., Echinocardium cordatum, Goniadopsis incerta and amphipods, depending on substrate. Also depending on substrate, deposit feeders may increase in importance towards the outer boundary of this zone. Although this survey did not cross the outer boundary of the outer turbulent zone, other transects that have extended to deeper water off high energy coasts have placed it at 20 to $40 \mathrm{~m}$ (Day et al., 1971; Field, 1971; Christie, 1976a).

Correspondence of these zones to the ciassicai communities of European waters (Petersen, 1913; Jones, 1950 ) is remote. Broadly, however, the inner turbulent zone may be similar to the boreal shallow sand associations (Tellina tenuis - Donax sordidus) while the outer turbulent zone may be similar to the boreal offshore sand assocation (Echinocardium, amphipods).

In conclusion we suggest that wave energy controls both the physical environment and the distribution of organisms along high energy coasts. The instability and turbulence caused by wave energy places physical limits on the ability of animals to colonise this zone. Meiofauna, occuring deep in the sand, experience this physical control less severely than the macrofauna. Macrofauna diversity and biomass both increase onshore and offshore from the break point where most wave energy is released. Even some distance outside the break point, however, wave effects on the bottom still exert a significant control on community structure and it is only below the outer turbulent zone that other factors become more important. More work is needed on the response of macrofauna to wave effects on the bottom and to changes in the wave regime such as during storms.

Acknowledgements. We thank several colleagues and students who assisted with diving, sampling and laboratory analysis, Professor John Field and Ms. E. Rumbak (University of Cape Town) for ordination of our similarity matrix and Ms. M. Maree for preparing figures. This work was funded by the South African National Committee for Oceanographic Research.

\section{LITERATURE CITED}

Barnard, J. L. (1963). Relationship of benthic amphipoda to invertebrate communities of inshore sublittoral sands of southern California. Pacif. Nat. 3: 439-467
Christie, N. D. (1976a). A numerical analysis of the distribution of a shallow sublittoral sand macrofauna along a transect at Lamberts Bay, South Africa. Trans. R. Soc. S. Afr. $42: 149-172$

Christie, N. D. (1976b). The efficiency and effectiveness of a diver-operated suction sampler on a homogeneous macrofauna. Estuar. coast. mar. Sci. 4: 687-693

Christie, N. D. Allen, J. C. (1972). A self contained diveroperated quantitative sampler for investigating the macrofauna of soft substrates. Trans. R. Soc. S. Afr. 40 299-307.

Clifford, H. T., Stephenson, W. (1975). An introduction to numerical classification. Academic Press, New York

Corey, S. (1970). The quantitative distribution of three cumacea (Crustacea, Peracarida) in Kames Bay, Scotland. Can. J, Zool. 48: 925-930

Coull, B. C. (1970). Shallow water meiobenthos of the Bermuda platform. Oecologia 4: 325-357

Dahl, E. (1952). Some aspects of the ecology and zonation of the fauna on sandy beaches. Oikos 4: 1-27

Day, J. H., Field, J. G., Montgomery, M. P. (1971). The use of numerical methods to determine the distribution of the benthic fauna across the continental shelf of North Carolina. J. Anim. Ecol. 40: 93-125

Field, J. G. (1971). A numerical analysis of changes in the soft-bottom fauna along a transect accross False Bay, South Africa. J. exp. mar. Biol. Ecol. 7: 215-253

Field, J. G., Clarke, K. R., Warwick, R. M. (1982). A practical strategy for analysing multispecies distribution patterns. Mar. Ecol. Prog. Ser. 8: 37-52

Gray, J. S. (1981). The ecology of marine sediments. Cambridge University Press, Cambridge

Harris, T. F. W. (1978). Review of coastal currents in South African waters. S. Afr. Natnl. Sci. Prog. Rep. 30: 1-103

Hill, G. W., Hunter, R. E. (1976). Interaction of biological and geological process in the beach and nearhore environments, northern Padre Island, Texas. In: Davis, $R$, A., Echington, P. (ed.) Beach and nearshore sedimentation. Society of economic palaeontologists and mineralogists, Tulsa, p. 169-187

Inman, D. L., Brush, B. M. (1973). The coastal challenge. Science, N. Y. 181: 20-32

Jones, N. S. (1950). Marine bottom communities. Biol. Rev. 25: 283-313

Masse, H. (1971a). Contribution à l'étude de la macrofaune de peuplements des sables fins infralittoraux des côtes de Provence. T. - La baie de Bandol. Tethys 2: 783-820

Masse, H. (1971b) Etude quantitative de la macrofaune de peuplements des sables fins infralittoraux. Il - La baie du Prado (Golfe de Marseille). Tethys 3: 113-158

Masse, H. (1972). Quantitative investigations of sandbottom macrofauna along the Mediterranean north-west coast. Mar. Biol. 15: 209-220

McIntyre, A. D., Eleftheriou, A. (1968). The bottom fauna of a flatfish nursery ground. J. mar. biol. Ass. U. K. 48: 113-142

McLachlan, A. (1977). Composition, distribution, abundance and biomass of the macrofauna and meiofauna of four sandy beaches. Zool. afr. 12: 279-306

McLachlan, A. (1980a). Exposed sandy beaches as semiclosed ecosystems. Mar environ. Res. 4: 59-63

McLachlan, A. (1980b). Intertidal zonation of macrofauna and stratification of meiofauna on high energy sandy beaches in the Eastern Cape, South Africa. Trans. R. Soc. S. Afr 44: 213-223

McLachlan, A. (1983). Sandy beach ecology - a review. In: McLachlan, A., Erasmus, T. (ed.) Sandy beaches as ecosystems. Junk, The Hague, p. 321-380 
McLachlan, A., Winter, P. E. D., Botha, L. (1977). Vertical and horizontal distribution of sub-littoral meiofauna in Algoa Bay, South Africa. Mar. Biol. 40: 355-364

McLachlan, A., Wooldridge, T., Van der Horst, G. (1979). Tidal migrations of the macrofauna on an exposed sandy beach in South Africa. J. Zool., Lond. 188: 433-442

Morgans, J. F. C. (1962). The benthic ecology of False Bay. Pat. II. Soft and rocky bottoms observed by diving and sampled by dredging, and the recognition of grounds. Trans. R. Soc. S. Afr. 36: 287-334

Orloci, L. (1978). Multivariate analysis in vegetation research. Junk, The Hague

Petersen, C. G. J. (1913). Valuation of the sea II. The animal communities of the sea bottom and their importance for marine zoogeography. Rep. Dan. Biol. Stn 21: 1-110

Rhoads, D. C., Young, D. K. (1970). The influence of deposit feeding organisms on sediment stability and community trophic structure. J. mar. Res. 28: 150-178
Riedl, R., Huang, N., Machan, R. (1972). The subtidal pump: a mechanism of interstitial water exchange by wave action. Mar. Biol. 13: 210-221

Sanders, H. L. (1968). Marine benthic diversity: a comparative study. Am. Nat. 102: 243-282

Shin, P. K. S. (1981). Temporal variations in a shallow subtidal community in North Bay (Inner Galway Bay), west coast of Ireland. Ir. Nat. J. 20:321-324

Shin, P. K. S. (1982). Multiple discriminant analysis of macrobenthic infaunal assemblages. J. exp. mar. Biol. Ecol. 59: $39-50$

Thomassin, B. A., Vivier, H.-N., Vitiello, P. (1976). Distribution de la meiofaune et de la macrofaune des sables coralliens de la retenue d'eau épirecifale du grand récif de Tuléar (Madagascar). J. exp. mar. Biol. Ecol. 22: 31-53

Wildish, D. J. (1977). Factors controlling marine and estuarune sublittoral macrofauna. Helgoländer wiss. Meeresunters. 30: $445-454$

This paper was presented by Professor L. Fishelson; it was accepted for printing on December 23, 1983 